\title{
Developmental pathway from leaves to galls induced by a sap-feeding insect on Schinus polygamus (Cav.) Cabrera (Anacardiaceae)
}

\author{
GRACIELA G. DIAS $^{1}$, BRUNO G. FERREIRA ${ }^{1}$, GILSON R.P. MOREIRA ${ }^{2}$ and ROSY M.S. ISAIAS ${ }^{1}$ \\ ${ }^{1}$ Universidade Federal de Minas Gerais, Instituto de Ciências Biológicas, Departamento de Botânica, \\ Av. Antônio Carlos, 6627, Campus Pampulha, 31270-901 Belo Horizonte, MG, Brasil \\ ${ }^{2}$ Programas de Pós-Graduação em Biologia Animal e Ecologia, Universidade Federal do Rio Grande do Sul, \\ Instituto de Biociências, Departamentos de Zoologia e Ecologia, \\ Av. Bento Gonçalves, 9500, Campus do Vale, 91501-970 Porto Alegre, RS, Brasil
}

Manuscript received on June 9, 2011; accepted for publication on September 19, 2011

\begin{abstract}
Galling sap-feeding insects are presumed to cause only minor changes in host plant tissues, because they usually do not require development of nutritive tissues for their own use. This premise was examined through comparison of the histometry, cytometry and anatomical development of non-galled leaves and galls of Calophya duvanae (Scott) (Hemiptera: Calophyidae) on Schinus polygamus (Cav.) Cabrera (Anacardiaceae). Cell fates changed from non-galled leaves to galls during the course of tissue differentiation. C. duvauae caused changes in dermal, ground, and vascular systems of the leaves of $S$. polygamus. Its feeding activity induced the homogenization of the parenchyma, and the neoformation of vascular bundles and trichomes. The histometric and cytometric data revealed compensatory effects of hyperplasia and cell hypertrophy in the epidermis, with hyperplasia predominating in the adaxial epidermis. There was a balance between these processes in the other tissues. Thus, we found major differences between the developmental pathways of non-galled leaves and galls. These changes were associated with phenotypic alterations related to shelter and appropriate microenvironmental conditions for the gall inducer. The nondifferentiation of a typical nutritive tissue in this case was compared to other non-phylogenetically related arthropod gall systems, and is suggested to result from convergence associated with the piercing feeding apparatus of the corresponding gall-inducer.
\end{abstract}

Key words: hemipteran gall, histometry, developmental patterns, cell fates.

\section{INTRODUCTION}

Closely related lineages of gall-inducing insects tend to influence their host plant tissues equally (Rohfritsch 1992), because of the similarities in their feeding habits. Conversely, differences in the feeding habits of gall inducers may explain, broadly, the morphological differences found

Correspondence to: Gilson R.P. Moreira

E-mail: gilson.moreira@ufrgs.br in galls (Crespi and Worobey 1998). This is particularly true for their inner cortex (Stone and Schönrogge 2003), where the differentiation of nutritive tissue commonly occurs. Galling insects that feed on parenchyma, for example mostly psylloid larvae (Raman 1987, Burckhardt 2005), induce galls with supposedly no differentiation of a typical nutritive tissue, and are thus less specialized compared to those where a nutritive tissue occurs. 
However, these contentions are still under debate. In fact, some authors have demonstrated the induction of a nutritive reserve in galls induced by sap-feeders (e.g., Meyer 1987, Oliveira et al. 2006, Moura et al. 2008). Herein, we measured tissue developmental changes between non-galled leaves and galls throughout ontogeny to establish possible convergences between gall systems involving gallinducers with similar mouth apparatus.

Independently of whether a nutritive tissue is formed, gall induction occurs in response either to oviposition or to the feeding activity of the first-instar nymph. In some cases, it may also be due to the feeding activity of the mother insect during oviposition (Rohfritsch 1992). The corresponding cell responses are induced by the combined effects of tissue injury and the injection of substances present in the saliva of the insect, which causes metabolic and hormonal imbalances in adjacent tissues (Hori 1992, Raman 2011). After gall induction, a number of cell divisions and hypertrophy occur (Mani 1964, Rohfritsch 1992, Oliveira et al. 2006), and increase as the insect's feeding activity continues (Rohfritsch 1992). Even for a typical gall-inducing phloem-feeding insect that causes localized impacts on plant cells, substantial changes in the plant to provide shelter and an appropriate environment during the gall inducer's life cycle are expected (Stone and Schönrogge 2003). Assuming that the peculiarities of the galls are related to the gall-inducer's feeding behavior, it is expected that the processes of differentiation and redifferentiation (sensu Lev-Yadun 2003) that occur from hosts to galls induced by sap-feeding insects are similar to those induced by other sucking arthropods.

We examined this question further by comparing through histometry, cytometry and anatomy the development of non-galled leaves of Schinus polygamus (Cav.) Cabrera (Anacardiaceae) with the leaf galls induced by a parenchyma sapfeeder, Calophya duvauae (Scott) (Hemiptera: Calophyidae). We searched for the existence of significant differences in the corresponding cell and tissue developmental pathways from both qualitative and quantitative perspectives. As described in detail by Fleig (1987, 1989), $S$. polygamus is a small, relatively common tree found more or less interspersed with fragments of semideciduous forests, herbaceous and shrub vegetation of southern Brazilian Campos (sensu Overbeck et al. 2007). Although galls induced by calophyids on species of Schinus have been reported by several investigators (Núñez and Sáiz 1994, Sáiz and Núñez 1997, 2000, Burckhardt and Basset 2000, Caballero and Lorini 2000, Burckhardt 2005), aspects of the anatomical development of these galls remain unknown. Thus, additional goals of the current study were: (1) to describe the developmental pattern of the host leaf tissues that are not influenced by the attack of $C$. duvauae; (2) to describe the anatomical development of the gall during the life cycle of $C$. duvauae; and (3) to quantify the reactions of cell hypertrophy or hyperplasia from non-galled tissues to mature galls, and their relationship to the alterations in $S$. polygamus cell fates.

\section{MATERIALS AND METHODS}

Non-galled leaves and galls were obtained from a population of Schinus polygamus (Cav.) Cabrera (Anacardiaceae) located in Canguçu Municipality, Rio Grande do Sul (RS), Brazil (32 ${ }^{\circ} 15^{\prime} 00^{\prime}$ 'S, $\left.65^{\circ} 58^{\prime} 00^{\prime \prime} \mathrm{W}\right)$. Samples were taken during June, September and December 2008, and March 2009. They consisted of 10 branches of 10 different individuals; from these branches, 10 galled and non-galled leaves and 6 apical portions of stems were randomly selected. The voucher of the fertile plant material is deposited at the herbarium of the Instituto de Biociências of the Universidade Federal do Rio Grande do Sul (UFRGS), Porto Alegre, RS, under accession number ICN 42884. The insect was identified following morphological criteria existing in Burckhardt and Basset (2000). Corresponding vouchers are deposited in the Entomology 
collection of the Laboratório de Morfologia e Comportamento de Insetos, Departamento de Zoologia, UFRGS, under accession number LMCI 202.

For the structural analyses, apical buds, young (from first to fourth nodes), and expanded (fifth and sixth nodes) non-galled leaves, galls and fragments with evidence of gall induction $(n=10$, for each type) were fixed in either 4\% Karnovsky in $0.1 \mathrm{mM}$ phosphate buffer for 24h (O'Brien and McCully 1981 , modified to $\mathrm{pH}=7.2)$ or in FAA $(37 \%$ formaldehyde, glacial acetic acid, and 50\% ethanol, 1:1:18, v/v) (Johansen 1940), and subsequently stored in $70 \%$ ethanol.

Semi-permanent slides were prepared with freehand cross-sections, stained with $0.5 \%$ safranin-astra blue (9:1) (Kraus and Arduin 1997). In the preparation of permanent slides, fragments were dehydrated in an n-butyl series, and embedded in Paraplast ${ }^{\circledR}$ (Kraus and Arduin 1997). Serial sections $(12-14 \mu \mathrm{m})$ were obtained in a rotary microtome and stained in $0.5 \%$ safranin-astra blue (9:1) (Kraus and Arduin 1997). The presence of crystals was verified by polarized light, and their chemical nature was tested with 5-10\% sulfuric acid (Chamberlain 1932). Presence of silica crystals was further tested with phenol (Johansen 1940, Kraus and Arduin 1997). Phenolic compounds were evidenced by the histochemical reaction with ferric chloride (Johansen 1940).

For the studies in scanning electron microscopy (SEM), the fragments with evidence of gall induction, and galls were separated according to the life stage of the insect, fixed in 4\% Karnovsky in $0.1 \mathrm{mM}$ phosphate buffer for $24 \mathrm{~h}\left(\mathrm{O}^{\prime}\right.$ Brien and McCully 1981, modified to $\mathrm{pH}=7.2$ ), post-fixed in $1 \%$ osmium tetroxide in $0.1 \mathrm{mM}$ phosphate buffer (pH 7.2), and then dehydrated in an ethanol series (Johansen 1940), followed by critical point drying with carbon dioxide (Bal-Tec CPD ${ }^{\circledR}$ 030). The material was sputter-coated with $30 \mathrm{~nm}$ of gold (BalTec $\left.\mathrm{SCD}^{\circledR} 050\right)$. Images were observed and captured in a scanning electron microscope (LEO EVO $\left.{ }^{\circledR} 40\right)$.
To obtain isolated epidermis, 10 non-galled leaves and 10 galls (with insect inducers in the fourth or fifth instars) were used. Fragments were immersed in $50 \%$ sodium hypochlorite at room temperature. After detachment, the epidermis was washed and stained with $0.5 \%$ safranin in $95 \%$ ethanol, and mounted with Kaiser's jelly glycerin (Johansen 1940). The diagrams were based on photomicrographs, and created using Adobe Photoshop ${ }^{\circledR}$ CS (Adobe Systems Inc. 1990-2003) and a tablet (Trust ${ }^{\mathbb{R}}$ TB-6300).

In parallel to structural observations, histometry can provide statistically reliable comparisons (Thiébaut 2000), and was used here to confirm and supplement the observations of contrasts between normal and altered morphogenesis. Histometric and cytometric data were obtained from photomicrographs of cross sections of the middle region of five fully expanded non-galled leaves and five mature galls, in the adaxial region opposite to the opening. The number of cells was counted from a transect. The thickness of the mesophyll of nongalled leaves, adaxial gall wall, vascular bundles in the middle portion, adaxial epidermis, and epidermis lining the chamber were evaluated $(n=40$ fields). The area of the spongy parenchyma cells in non-galled leaves, the cells of the inner cortex of the galls, the adaxial epidermis, and the epidermis lining the chamber ( $\mathrm{n}=50$ fields) were also evaluated. The measurements were performed with Axion Vision Zeiss ${ }^{\circledR}$ software, and subjected to statistical analyses in JMP (SAS Institute, U.S.A., 1989-2002). The data did not pass normality tests (Shapiro-Wilk tests) and therefore were compared by a nonparametric Kruskal-Wallis test, followed by Dunn's multiple comparison tests $(\alpha=0.05)$.

\section{RESULTS}

\section{LEAF DEVELOPMENT}

The leaves of Schinus polygamus (Cav.) Cabrera are simple, glabrous, and elliptical at maturity, with a spiral alternate phyllotaxy (Fig. 1A). 

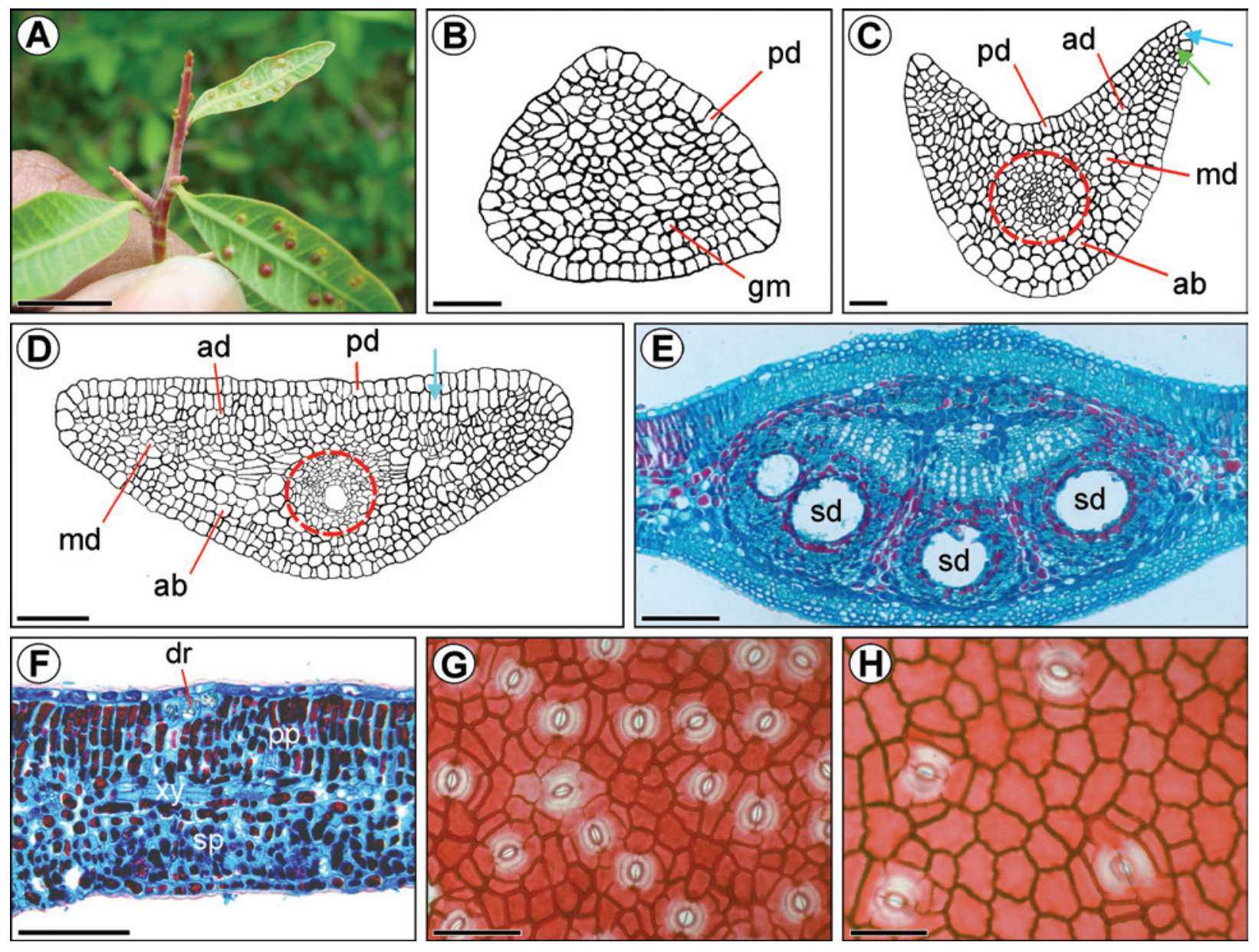

Fig. 1 - Development of the leaves of Schinus polygamus: A) Shoot apex with spiral alternate phyllotaxy; B-D) Diagrams of a leaf primordium in transverse section at the first, second and fourth nodes, respectively; in $\mathrm{C}$, the red circle indicates the procambium, and the arrows, the marginal (blue) and submarginal (green) initials; in D, the palisade parenchyma begins to elongate (blue arrow) and the procambium (red circle) divides periclinally, originating the vascular bundle with the secretory duct; E) Midrib of the completely expanded leaf; sixth node; F) Dorsiventral mesophyll of mature leaf lamina, with the palisade parenchyma facing the adaxial surface and the 6-8 layered, spongy parenchyma; G) Abaxial

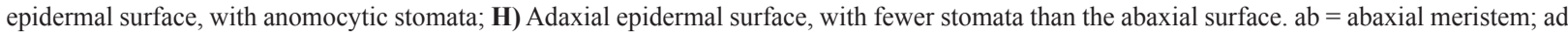
$=$ adaxial meristem $; \mathrm{dr}=$ druses $; \mathrm{md}=$ median meristem $; \mathrm{gm}=$ ground meristem; $\mathrm{pd}=$ protoderm; $\mathrm{pp}=$ palisade parenchyma; $\mathrm{sd}=\mathrm{secretory}$ duct; $\mathrm{sp}=$ spongy parenchyma; $\mathrm{xy}=\mathrm{xylem}$. Bars $=1 \mathrm{~cm}$ and 20, 20,60,100, 100, 25, $25 \mu \mathrm{m}$, respectively.

At the shoot apex, the promeristem initiates its differentiation by anticlinal divisions of L1. During leaf development, the protoderm is the first meristem to differentiate, followed by the ground meristem, where the procambium arises. The palisade parenchyma is the last tissue to differentiate, when the leaves get to the sixth node, and are completely differentiated.

The protoderm and the ground meristem are already differentiated at the first leaf primordium
(Fig. 1B). In the protoderm, only anticlinal divisions take place, while in the submarginal layers, anticlinal and periclinal divisions occur. At the second node, the cells of the ground meristem divide anticlinally and periclinally, resulting in an increase of isodiametric cell layers (Fig. 1C). In the middlemeristem, the procambial cells differentiate and divide in several planes, giving rise to grouped small cells. Phenolic idioblasts start to differentiate. At the third node, the protoderm of the leaf primordium divides anticlinally. The ground 
meristem has three distinct layers: adaxial, abaxial and middle meristem. Schizogenous secretory ducts are associated with the phloem. At the fourth node, the adaxial meristem divides both anticlinally and periclinally (Fig. 1D). The procambium divides periclinally. The middle meristem, in addition to the vascular system, gives rise to the inner layers of the spongy parenchyma. The abaxial meristem has two layers. In this stage of development, the second-order veins begin to differentiate in the middle layers of the ground meristem, without secretory ducts. At the fifth node, the palisade parenchyma is 2-3 layered and anticlinally elongated, and more cells in the spongy parenchyma and the stomata differentiate. The midrib is almost completely differentiated, with 2-4 secretory ducts associated with the phloem (Fig. 1E). The frequency of idioblasts with phenolic compounds gradually increases during the leaf development.

The leaf lamina is completely differentiated at the sixth node, and the midrib is biconvex (Fig. 1E). The vascular system is constituted of 3-5 units with collateral arrangement and secondary growth. The epithelial cells and the vascular parenchyma cells are filled with phenolic compounds, as are the cells of the endodermis and the pericycle. Some individual druses of calcium oxalate were observed in the endodermis. At the cortex of the midrib, there are 2-3 layers of annular collenchyma and isodiametric parenchyma cells. The second-order veins are collateral, and also have secretory ducts, unlike the smaller veins which have few vascular cells.

In the mature leaf lamina, the mesophyll is dorsiventral, with biseriate palisade parenchyma (Fig. 1F) facing the adaxial surface, and spongy parenchyma with a variable number of cell layers, and interspersed vascular bundles. Most of the cells of the mesophyll are filled with phenolic compounds. The leaf is amphistomatic, with periclinally elongated epidermal cells in cross section, and slightly sinuous anticlinal walls in frontal view (Fig. 1G). The stomata are anomocytic (Fig. 1H).

\section{GALL DEVELOPMENT}

General aspects. Galls induced by $C$. duvauae are isolated or grouped (Fig. 2A), and form a large chamber (Fig. 2B), which shelters one gall inducer. The induction occurs at the abaxial surface and causes a depression in the leaf lamina, followed by the formation of emergences with trichomes that close the opening of the gall in the growth and developmental phase. The maturation phase is characterized by an increase in gall size. Suberization of the epidermis covering the nymphal chamber and the opening region occurs in the senescent phase.

Anatomical features. The insertion of a pedunculated egg between two epidermal cells causes a local increase in phenolics accumulation (Fig. 2C). After hatching, the first-instar nymph inserts its stylets into epidermal cells, and continues inducing the cell alterations started by the egg's presence. The mesophyll tissues develop, involving the nymph (Fig. 2D). The gall is closed by trichome differentiation, and by divisions of the cells of the abaxial epidermis and of the adjacent parenchyma (Fig. 2E, F). There is no welding, but only overlapping of the trichomes. The epidermis of the nymphal chamber is continuous with the abaxial surface, and its cells successively divide anticlinally. The adaxial epidermis also divides anticlinally, following the growth of the gall, which is projected to this surface. Emergences consisting of parenchyma and epidermal cells differentiate and give rise to the region of the gall opening, where the adult will emerge.

During gall development, the cells of the spongy parenchyma become homogeneous and divide, resulting in an increase in gall size. Some cells of this parenchyma redifferentiate into procambial strands. The neoformed vascular bundles have secretory ducts that will be completely differentiated at the end of this phase. The abaxial portion of the gall is not vascularized, and has isodiametric epidermal and parenchyma cells. 
In the maturation phase, the gall contains several layers of parenchyma, large vascular bundles in the adaxial portion, and secretory ducts with large lumens. The trichomes of the ostiole lignify and project inward and outward to the nymphal chamber (Fig. 2G-H). A large amount of calcium oxalate crystals accumulates in the epidermal cell walls immediately outside the opening (Fig. 2I). These inclusions are absent from the cells surrounding the nymphal chamber.
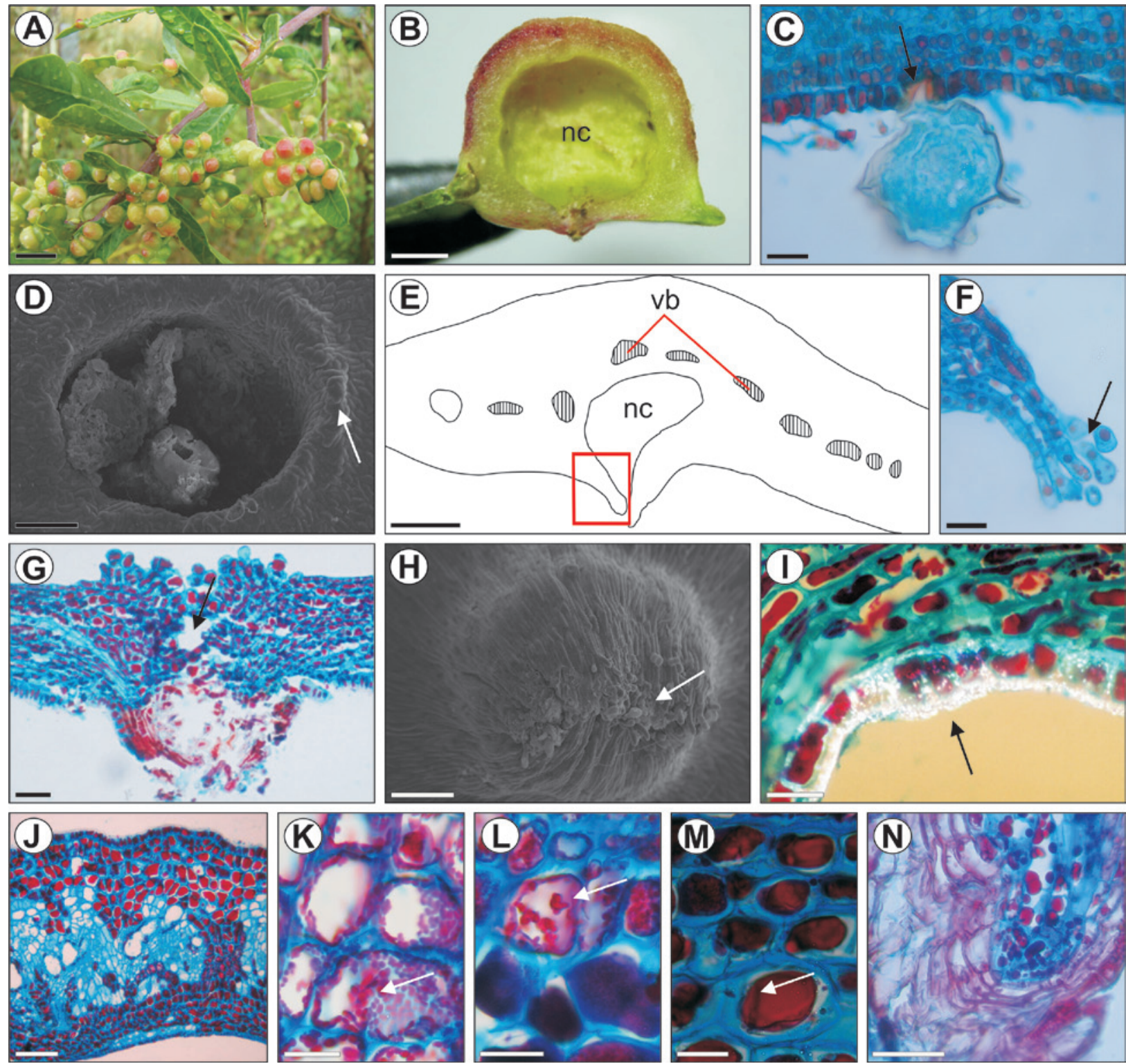

Fig. 2 - Development of the galls of Calophya duvauae on the leaves of Schinus polygamus: A) Shoot with several galls; B) Cross section of a mature gall, showing the large nymphal chamber (nc); C) Egg inserted (arrow) in the abaxial epidermis; D) Evagination of leaf tissues around insect body, under scanning electron microscopy (arrow); E) Diagram of a cross section of the gall during the growth and developmental phases, showing the nymphal chamber and position of the vascular bundles; F) Detail (red rectangle in $\mathbf{E}$ ) of the trichomes at the opening of the gall (arrow); G) Detail of the region of the gall opening, with lignified trichomes (arrow); H) Trichomes in the region of the opening (arrow), scanning electron micrograph; I) Abaxial epidermis near the opening, with calcium oxalate crystals (arrow); J) Adaxial region of the gall, highly vascularized and with parenchyma cells containing phenolics (reddish); K-M) Progressive accumulation of phenolics in the gall cortex (arrows); N) Cicatrization tissue (suber) in the opening of a senescent gall. $\mathrm{nc}=$ nymphal chamber; $\mathrm{vb}=$ vascular bundle. Bars $=1 \mathrm{~cm}, 1 \mathrm{~mm}$, and 20, 100, 150, 25, 50, 100, 20, 100, 20, 20, 20, 40 $\mu \mathrm{m}$, respectively. 
The vascularization develops only in the adaxial portion of the gall, where several cells of the parenchyma, vascular parenchyma and secretory epithelium are filled with phenolic compounds (Fig. 2J). Druses abound in the adaxial mesophyll. The adaxial surface of the epidermis has isodiametric cells with a thick cuticle. The phenolic content of the parenchyma and epidermal cells is variable, and is higher in the adaxial cortex (Fig. 2K-M).

In the senescent phase, the gall inducer emerges through the gall opening, which enlarges. The major anatomical alterations in this phase are the absence of trichomes, and the suberization of the opening region (Fig. $2 \mathrm{~N}$ ) and the nymphal chamber epidermis adjacent to it. Some epidermal and parenchyma cells exhibit altered forms and contents.

The gall induction causes alterations and redifferentiation of the leaf tissues. In this process, palisade parenchyma originates the outer adaxial cortex. The spongy parenchyma redifferentiates into the inner adaxial cortex, the abaxial cortex and vascular bundles. The epidermis redifferentiates into the dermal system of the nymphal chamber (Fig. 3).

Cytometry and Histometry. Every measured cytometric and histometric parameter was altered during gall development, except the thickness of the adaxial epidermis (Fig. 4). The number of cell layers and vascular bundles, and the mesophyll thickness in the mature galls (MG) are almost twice those of non-galled leaves (NGL) (Fig. $4 \mathrm{~A}-\mathrm{C})$. The thickness of the epidermis covering the nymphal chamber is greatly reduced (Fig. $4 \mathrm{E})$. The area of the parenchyma cells increases (Fig. 4F), and the areas of the adaxial epidermal cells and of the nymphal chamber epidermis decrease (Fig. 4G-H).

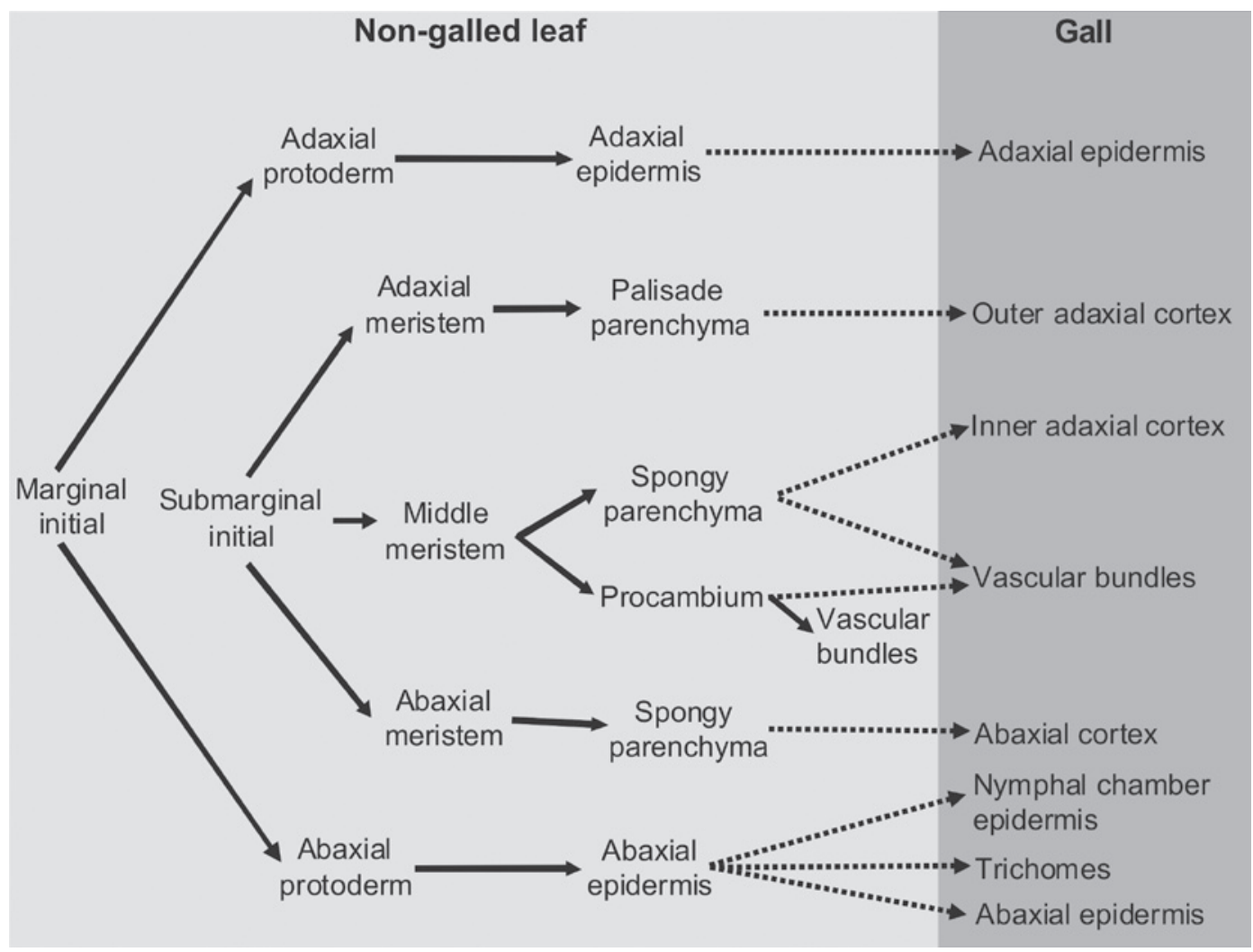

Fig. 3 - Diagrammatic representation of leaf morphogenesis (solid arrows) and of Calophya duvauae gall formation (dotted arrows) on Schinus polygamus. 

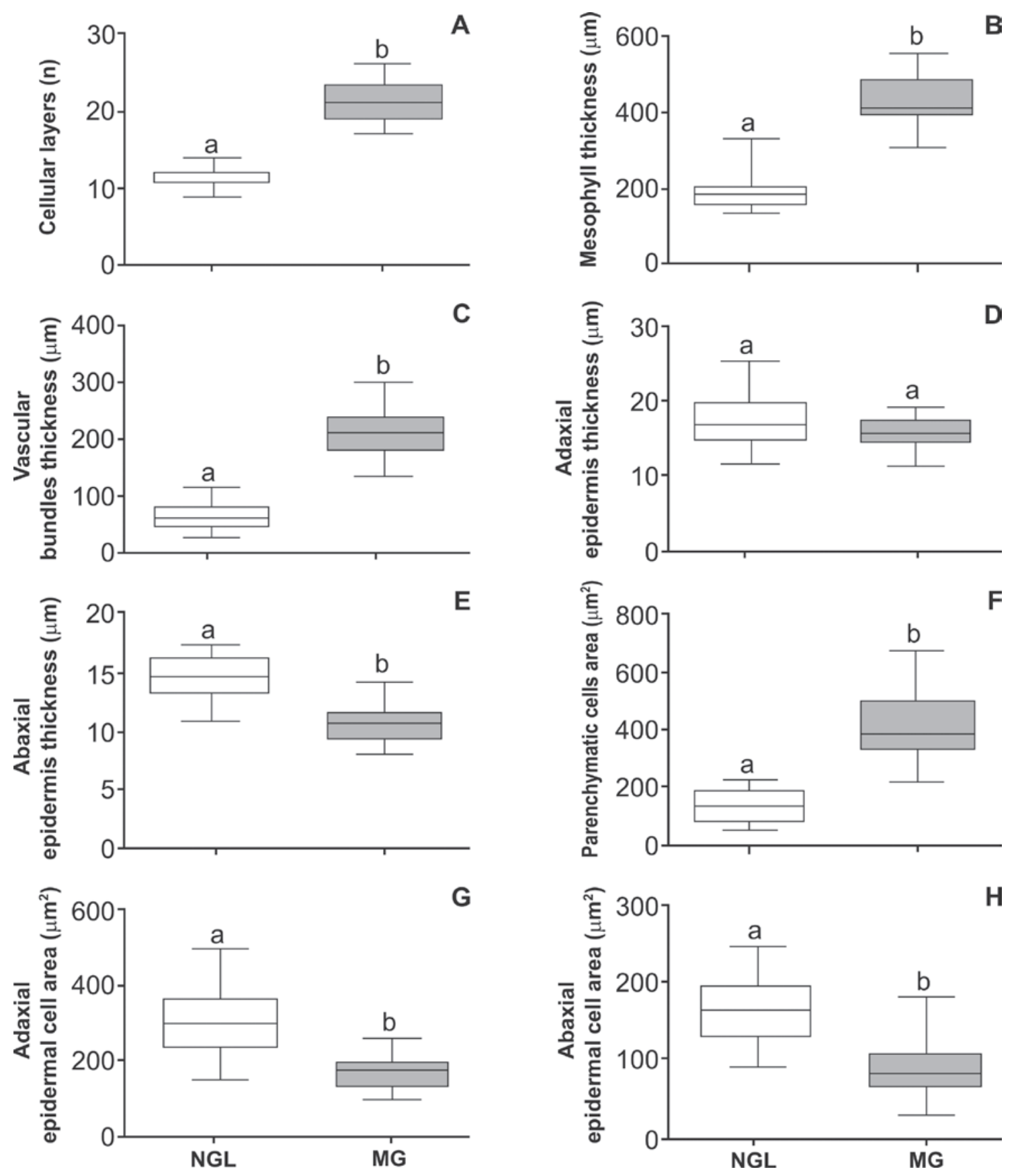

Fig. 4 - Cytological and histometrical analyses of cross sections of non-galled leaves (NGL) of Schinus polygamus and mature galls (MG) of Calophya duvauae. Bars followed by the same letters are not significantly different (Kruskal-Wallis test, followed by Dunn's multiple comparison tests; $\alpha=0.05$ ). Box plots represent the medians and corresponding quartiles.

\section{DISCUSSION}

Our data clearly showed that there are pronounced anatomical changes caused by the presence and feeding habit of the gall inducer. Compared to two other similar systems induced by galling fluid- feeders that were studied in detail in this regard, the galls of $S$. polygamus - C. duvauae are more similar to those of Lantana camara (Verbenaceae) - A. lantanae (Acari: Eriophyidae) than to those of Copaifera langsdorffii (Fabaceae) - Cecidomyiidae 
(Diptera). The latter develop a specialized nutritive tissue in response to the feeding habit of the gallinducer (Oliveira and Isaias 2010). Although considered fluid feeders, cecidomyiid larvae have a complex feeding apparatus that is not homologous to that of the psylloids (Bronner 1992). A. lantanae, on the other hand, induces galls with a homogeneous parenchyma that does not lignify and suberize during senescence, characteristics associated with their sucking habit (Moura et al. 2009). Thus, our results indicate the existence of a convergence in the tissue composition of $C$. duvauae galls with those of $A$. lantanae, presumably associated with their similar feeding apparatus (both have piercing stylets; see Roberts et al. 1994, and Buckhardt 2005), given that are distantly phylogenetically related (belong to different arthropod classes). Two additional peculiarities distinguish these systems, but apparently play no major role in the existence of such a convergence: first, their galls have a different number of inducers per chamber; i.e., $L$. camara houses a colony of $A$. lantanae in each gall, whereas $S$. polygamus houses one $C$. duvauae per chamber; and second, their galls have different shapes; i.e. A. lantanae induces crinkle-leaf galls with an irregular, hairy surface (Moura et al. 2008), and $C$. duvauae induces pouch galls with regular, non-hairy surfaces, as described herein.

In two other Neotropical, fluid-feeder gall inducers, Bacharopelma dracunculifolia (Arduin et al. 2005) and Euphalerus ostreoides (Oliveira et al. 2006, Isaias et al. in press), similar patterns were observed, such as in relation to the homogenization of the parenchyma and hyperplasia of the vascular bundles. However, regarding the epidermis and secretory cells, each of these gall systems showed some peculiarities, indicating the different role of each insect species in determining the gall phenotype. As rounded galls, those induced by $C$. duvauae have cells whose pattern of elongation drastically changed. The mass of homogeneous cells are in the majority isodiametric, not elongated or braciform as in the palisade and spongy parenchyma, and seem to be the cause of the gall shape. In the case of the bivalve-shaped galls of Lonchocarpus muehlbergianus, for instance, the cells elongate anticlinally to generate the gall morphotype (Isaias et al. in press). This gives further support for the specific role of the inducers in causing subtle differences in gall morphologies, independently of their similar feeding behaviors.

\section{LEAF DEVELOPMENT}

The leaf development of $S$. polygamus follows the pattern described by Foster (1936) for Pelargonium zonale (Geraniaceae), and of some other simple leaves (Fahn 1990). The adaxial meristem initiates the palisade parenchyma, and the middle meristem originates the procambial cells and half of the spongy parenchyma. The other half differentiates from the abaxial meristem. A similar pattern was described by Oliveira and Isaias (2010) for the development of the leaflets of C. langsdorffii.

The leaf epidermis originates exclusively from the protoderm, and is one-layered from the first to the sixth node, when the leaves are totally expanded. The adaxial surface of the epidermis originates from the adaxial protoderm, and the abaxial epidermis from the abaxial protoderm (Fahn 1990, Moura et al. 2009, Oliveira and Isaias 2010). In the plants of $S$. polygamus studied here, trichomes are rare, similarly to the observations of Fleig (1985). The stomata are numerous and associated with the veins, as described by Alvarez et al. (2008) for another Anacardiaceae, Pistacia terebinthus.

The procambium cells originate from the middle meristem layers, as observed for $P$. zonale, L. camara and C. langsdorffii (Foster 1936, Moura et al. 2009, Oliveira and Isaias 2010). The midrib begins to differentiate at the second node, and the secondary veins at the fourth node. The secretory epithelium of the ducts also originates from the middle layer, and is always associated with the phloem, a common feature in Anacardiaceae 
(Solereder 1908, Metcalfe and Chalk 1983, Carmello-Guerreiro and Paoli 2005, Simpson 2006, Lacchia and Carmello-Guerreiro 2009). These gum resin secretory ducts (Fahn 1979) begin to differentiate at the third node, and their presence may function in the early protection of the expanding leaves, similarly to the phenolic compounds detected in the mesophyll cells since the second node.

\section{GALL DEVELOPMENT}

During oviposition, the egg stalk of $C$. duvauae is inserted precisely between two epidermal cells. According to Burckhardt (2005), most galls of Psylloidea are induced by the feeding activity of the nymph. However, in the case of $C$. duvauae, phenolics accumulation and cell divisions were observed in response to the presence of the egg, resulting in the onset of a depression in the leaf. Then, the nymph is responsible for continuing the stimuli that began at the time of oviposition. Plant responses to insect oviposition, such as the secretion of ovicidal and volatile attractive substances, and hypersensitivity reactions are known, and they can also be found in galls (Rohfritsch 1992, Hilker and Meiners 2006). The depression around the oviposition site seems to follow the patterns previously observed in galls of some Psylloidea (Bouyjou and Nguyen 1974, Taylor 1992). The cells underlying the egg and later the nymph divide anticlinally and form the epidermis of the nymphal chamber. This tissue does not have differentiated stomata, and has small cells covered with a thin cuticle, as observed in the galls of $P$. terebinthus (Alvarez et al. 2009).

At the edges of the emergences, the epidermal cells redifferentiate into trichoblasts that increase in size and eventually obliterate the opening. The trichomes are related to mechanical protection against invaders, such as predators, parasitoids and cecidophages, and help to stabilize the temperature and humidity within the gall chamber (Johnson
1975, Arduin et al. 2005, Oliveira et al. 2006, Alvarez et al. 2009). In galls induced by Forda formicaria in $P$. terebinthus, the trichomes are reminiscent of the young stage of the leaflets; in $S$. polygamus, however, these epidermal appendages are neoformed, similarly to what was observed on the valves of galls induced by Euphalerus ostreoides (Hemiptera: Psyllidae) on L. muehlbergianus Hassl. (Fabaceae) (Oliveira et al. 2006).

In galls induced in mature tissues, cell redifferentiation is necessary, generating specialized tissues (Oliveira and Isaias 2009). In galls of $C$. duvauae on $S$. polygamus, either the vascular or the ground systems are derived secondarily from cells of the ground meristem. Because of their relative position on the leaf surface, it is possible to trace the origin of the gall tissues redifferentiated from palisade and spongy parenchyma.

In response to the stimuli of gall induction, the parenchyma cells recover their ability to divide and hypertrophy. Cell divisions occur in several planes, increasing the number of cell layers and the thickness of the mesophyll, and originating the homogeneous parenchyma cortex. Both the homogenization of the parenchyma and cell hypertrophy are common phenomena in the formation of galls, and have been observed in other Neotropical systems (Souza et al. 2000, Moura et al. 2008, Moura et al. 2009, Oliveira and Isaias 2010). These phenomena are linked to reduced photosynthetic capacity in some galls (Moura et al. 2008), and are related to the new functions of the mesophyll, such as a feeding site for the insect and a protective barrier (Mani 1964, Rohfritsch 1992, Moura et al. 2008). Hence, some plants infested with galls have shown less growth and productivity (Gonzáles et al. 2005).

The accumulation of crystals of different shapes also seems to be related to the protection of the insect (Fernandes et al. 1989, Arduin and Kraus 1995, Alvarez et al. 2009). Druses of calcium oxalate are observed in the adaxial cortex of the gall and in the outer epidermis, especially near the 
opening. Crystal accumulation is a product of the activity of the gall inducer, which usually does not cause the appearance of novel features in the host plant. Moreover, it is a product of the redirection of substances and patterns of development that are already present in the host organ (Rohfritsch and Shorthouse 1982, Schönrogge et al. 2000).

The neoformation of vascular bundles is observed throughout the adaxial portion of the gall, similarly to the midrib gall of $C$. langsdorffii (Oliveira and Isaias 2010). These bundles are essential for the nourishment of the cells of the gall and of the gall inducer, which feeds by inserting its stylets into phloem cells. In galls of S. polygamus, these bundles originate from the middle layer of the spongy parenchyma, indicating a return of the meristematic potentialities of these cells, as is often reported for galls (Mani 1992, Isaias et al. 2000, Oliveira and Isaias 2010). There is also a considerable increase in the thickness of these bundles, resulting from the increased number of vascular cells. This hyperplasia of vascular bundles was also observed in galls of $E$. ostreoides, a galling phloem feeder, on $L$. muehlbergianus (Oliveira et al. 2006). The absence of abaxial vascular bundles in the cortex of the gall is explained by the origin of this region, a product of the redifferentiation of the outer layers of spongy parenchyma, which were not vascularized.

In the galls, the secretory ducts associated with the phloem only complete their differentiation in the early stages of the maturation phase. This confirms the return to the meristematic activity of the middle layers of spongy parenchyma, since the pattern observed in the gall repeats the development of the non-galled leaf: first the procambial strands differentiate, and from these, the secretory ducts.

The cytometric and histometric results confirm the cell changes during maturation of the gall of $C$. duvauae on S. polygamus. The cells lining the nymphal chamber, in direct contact with the insect, showed reduced thickness and cell area. The thickness of the adaxial epidermis remained similar to that of the leaves, but with a reduction in cell area. These changes in the epidermis reflect the great hyperplasia of this tissue, resulting in the growth of the gall. The increase in cell number and thickness of the mesophyll and vascular bundles, as well as the considerable increase in the area of parenchyma cells, reflect the hyperplasia and hypertrophy typical of gall formation (Mani 1964, Oliveira and Isaias 2010, Moura et al. 2009).

When the insect completes its development, it escapes through the gall ostiole obliterated by trichomes. Later on, during the senescence stage, no trichomes are observed in the gall opening, and they may have been mechanically detached when the insect emerged from the gall. This region has a phellem covering similar to that observed in galls of L. camara, possibly as an indication of the end of the gall-inducer feeding stimulus, as proposed by Moura et al. (2009). The abaxial portion of the gall degrades rapidly, and its tissues are disorganized.

Oliveira and Isaias (2010) suggested that differences in histometric data denoted the relationship between the development of tissues and the final morphology in a gall morphotype of $C$. langsdorfii. In the gall studied herein, this relationship was confirmed, as the round shape could be a consequence of the homogenization of the mesophyll cells. This represents an additional step in understanding the gall phenotype as a product of the alteration in cell fates and the corresponding pattern of growth and elongation.

C. duvauae alters the morphogenesis of its host leaves on S. polygamus, causing homogenization of the parenchyma and neoformation of vascular bundles and trichomes on the ostiole, and suppressing the development of stomata in the epidermis lining the nymphal chamber. The histometric analyses revealed compensatory effects of hyperplasia in the epidermis, where cell hypertrophy is limited. In the gall cortex, however, there is equilibrium between the two processes, resulting in the gall growth and in the final spherical shape. 


\section{FINAL COMMENTS}

The most affected tissues were those derived from the submarginal initials, which differentiated the palisade and the spongy parenchyma. Hypertrophy and hyperplasic phenomena also occurred in the cells of these mesophyll layers, leading to the homogenization and the new functional design of the gall structure.

Galls have been recently seen as extended phenotypes of gall-inducer genes (sensu Dawkins 1982), and most gall-inducers, as parasites that might in some way control gall development (Crespi and Worobey 1998, Stone and Schönrogge 2003). Contrary to other taxa, however, in which a control can be inferred from phylogenetic patterns in gall evolution, in aphids, gall midges and thrips, the gall form may be occasionally associated with differences in the gall-inducer feeding behaviors (Stone and Schönrogge 2003). This seems to be also the case for the calophyid studied herein studied that is also a sap-feeder. In summary, our data showed that major anatomical changes occur in galls induced by C. duvauae on S. polygamus leaves, which may be linked to the piercing feeding apparatus of the inducer. However, no typical nutritive tissue differentiates. This is a strong indication that this pattern results from convergent evolution, as it has been similarly observed not only in galls induced by other insects, but also by distantly related arthropod lineages (e.g., Acari) that belong to the same feeding guild. Thus, these changes are not related to the formation of a nutritive tissue, but presumably provide an adequate shelter and microenvironment for growth and development of the gall-inducer, for which the corresponding adaptive value remains to be tested.

\section{ACKNOWLEDGMENTS}

The authors thank the Electron Microscopy Laboratory of the Universidade Federal de Lavras for the use of SEM facilities, and Thiago Magalhães (UFMG) for helping in the SEM analyses. Thanks are also due to Denis Santos Silva (UFRGS) for editing the plates, and to Janet Reid for editing the text. G.G. Dias and B.G. Ferreira were financially supported by Capes and $\mathrm{CNPq}$ master's and undergraduate fellowships, respectively. R.M.S. Isaias and G.R.P. Moreira benefited from $\mathrm{CNPq}$ grants (process numbers 307488/2009-8 and 304458/2008-2, respectively).

\section{RESUMO}

Supõe-se que insetos galhadores de hábito sugador causam menos alterações nos tecidos vegetais, já que eles usualmente não necessitam de um tecido nutritivo diferenciado para sua alimentação. Essa premissa foi examinada pelo uso da histometria, citometria e comparação do desenvolvimento de folhas não galhadas e galhas de Calophya duvanae (Scott) (Hemiptera: Calophyidae) em Schinus polygamus (Cav.) Cabrera (Anacardiaceae). As galhas demonstraram alterações nos tipos celulares durante a diferenciação tecidual. $C$. duvauae causou mudanças nos sistemas de revestimento, fundamental e vascular das folhas de S. polygamus. A atividade alimentar induziu a homogeneização do parênquima, a neoformação dos tecidos vasculares e tricomas. Os dados histométricos revelaram efeitos compensatórios de hiperplasia e hipertrofia celular na epiderme, predominando a hiperplasia na epiderme adaxial. Houve um balanço entre esses processos nos demais tecidos. Assim, obtivemos diferenças expressivas entre as trajetórias de desenvolvimento das folhas com e sem galhas. Essas alterações foram associadas a alterações fenotípicas relacionadas à provisão de abrigo e microambiente adequado ao galhador. Anão diferenciação de um tecido nutritivo típico neste caso foi comparada com sistemas de galhas induzidas por outros artrópodes, sendo sugerido como uma convergência associada ao aparato alimentar perfurador do agente indutor.

Palavras-chave: galha de hemíptero, histometria, padrão de desenvolvimento, destinos celulares.

\section{REFERENCES}

Alvarez R, Encina A AND PÉReZ HN. 2008. Pistacia terebinthus L. leaflets: an anatomical study. Plant Syst Evol 272: 107-118. 
Alvarez R, Encina A AND PÉREZ HN. 2009. Histological aspects of three Pistacia terebinthus galls induced by three different aphids: Paracletus cimiciformis, Forda marginata and Forda formicaria. Plant Sci 176: 303-314.

Arduin M, Fernandes GW and Kraus JE. 2005. Morphogenesis of galls induced by Baccharopelma dracunculifoliae (Hemiptera: Psyllidae) on Baccharis dracunculifolia (Asteraceae) leaves. Braz J Biol 65: 559-571.

ARduIn M AND KraUS JE. 1995. Anatomia e ontogenia de galhas foliares de Piptadenia gonoacantha (Fabales, Mimosaceae). Bol Bot Univ São Paulo 14: 109-130.

Bouyjou B AND NGuYen TX. 1974. Observations sur la morphogènese et la structure de la galle de Trioza alacris Flor. (Homoptera-Psyllidae) sur Laurus nobilis L. Marcellia 38: 49-55.

BRONNER R. 1992. The role of nutritive cells in nutrition of cynipids and cecidomyiids. In: SHORTHOUSE JD AND ROHFRITSCH O (Eds), Biology of Insect-Induced Galls. New York: Oxford University Press, p. 118-140.

BURCKHARDT D. 2005. Biology, ecology and evolution of pall-inducing psyllids (Hemiptera: Psylloidea). In: RAMAN A, SHAEFER CW AND WITHERS TM (Eds), Biology, Ecology, and Evolution of Gall-Inducing Arthropods. Plymouth: Science Publishers, p. 143-157.

BURCKHARDT D AND BASSET Y. 2000. The jumping plant-lice (Hemiptera, Psylloidea) associated with Schinus (Anacardiaceae): systematics, biogeography and host plant relationships. J Nat Hist 34: 57-155.

CABAllero PP AND LoRINI H. 2000. Does resource concentration affect attack by galling and folivorous insects on Schinus polygamus (Cav.) Cabr. (Anacardiaceae)? Rev Chil Entomol 26: 89-92.

CARMELlo-Guerreiro SM AND PAOLli AAS. 2005. Anatomy of the pericarp and seed-coat of Lithraea molleoides (Vell.) Engl. (Anacardiaceae) with taxonomic notes. Braz Arch Biol Technol 48: 599-610.

Chamberlain CJ. 1932. Methods in Plant Histology. $5^{\text {th }}$ ed., Chicago: University Press, $416 \mathrm{p}$.

CRESPI B AND Worobey M. 1998. Comparative analysis of gall morphology in Australian gall thrips: the evolution of extended phenotypes. Evolution 52: 1686-1696.

DAWKInS R. 1982. The Extended Phenotype: The Gene as a Unit of Selection. Oxford: Oxford University Press, 313 p.

FAHN A. 1979. Secretory Tissues in Plants. London: Academic Press, 302 p.

FAHN A. 1990. Plant Anatomy. Oxford: Pergamon Press, 600 p.

FERNANDES GW, PRESZLER RW AND GRIM JN. 1989. The occurrence of crystals in a cynipid leaf gall on Quercus turbinella. Beiträge zur Biologie der Pflanzen 65: 377-383.

FLEIG M. 1985. Análise da variação foliar de Schinus polygamus (Cav.) Cabrera (Anacardiaceae). Iheringia 33: 3-16.

FLEIG M. 1987. Anacardiaceae. (Flora Ilustrada do Rio Grande do Sul, 18) Bol Inst Biociênc 42: 1-72.

FLEIG M. 1989. Anacardiáceas. In: REITZ R (Ed), Flora Ilustrada Catarinense. Itajaí: Herbário Barbosa Rodrigues, 64 p.
FOSTER AS. 1936. Leaf differentiation in angiosperms. Bot Rev 2: 349-372.

GonzÁles WL, CABALlero PP AND MEdel R. 2005. Gallerinduced reduction of shoot growth and fruit production in the shrub Colliguaja integerrima (Euphorbiaceae). Rev Chil Hist Nat 78: 393-399.

HILKER M AND MEINERS T. 2006. Early herbivore alert: Insect eggs induce plant defense. J Chem Ecol 32: 1379-1397.

HORI K. 1992. Insect secretions and their effect on plant growth, with special reference to hemipterans. In: SHORTHOUSE JD AND ROHFRITSCH O (Eds), Biology of Insect-Induced Galls. New York: Oxford University Press, p. 157-170.

ISAIAS RMS, OliVEIRA DC AND CARNEIRO RGS. 2011. Role of Euphalerus ostreoides (Hemiptera: Psylloidea) in manipulating leaflet ontogenesis of Lonchocarpus muehlbergianus (Fabaceae). Botany 89: 581-592.

ISAIAS RMS, SOARES GLG, CHRISTIANO JCS AND GONÇALVES SJMR. 2000. Análise comparativa entre as defesas mecânicas e químicas de Aspidosperma australe Müell. Arg. e Aspidosperma cylindrocarpon Müell. Arg. (Apocynaceae) contra herbivoria. Floresta Ambient 7: 19-30.

JoHANSEN DA. 1940. Plant Microtechnique. New York: McGraw-Hill Book Co. Inc., 523 p.

JOHNSON HB. 1975. Plant pubescence: An ecological perspective. Bot Rev 41: 233-258.

Kraus JE AND ARduIn M. 1997. Manual Básico de Métodos em Morfologia Vegetal. Seropédica: EDUR, 198 p.

LACCHIA APS AND CARMELlO-GUERREIRO SM. 2009. Aspectos ultra-estruturais dos canais secretores em órgãos vegetativos e reprodutivos de Anacardiaceae. Acta Bot Bras 23: 376-388.

LEV-YADUN S. 2003. Stem cells in plants are differentiated too. Curr Opin Plant Biol 4: 93-100.

MANI MS. 1964. Ecology of Plant Galls. The Hague: Dr. W. Junk Publishers, 434 p.

MANI MS. 1992. Introduction to Cecidology. In: SHORTHOUSE JD AND ROHFRITSCH O (Eds), Biology of InsectInduced Galls. New York: Oxford University Press, p. 3-7.

MetCAlfe CR AND Chalk L. 1983. Anatomy of the Dicotyledons, $2^{\text {nd }}$ ed., Oxford: Clarendon Press, 297 p.

MEYER J. 1987. Plant Galls and Gall Inducers. Berlin: Gebrüder Bornträger, $291 \mathrm{p}$.

Moura MZD, SOARES GLG AND ISAIAS RMS. 2008. Speciesspecific changes in tissue morphogenesis induced by two arthropod leaf gallers in Lantana camara (Verbenaceae). Aust J Bot 56: 153-160.

Moura MZD, SOARES GLG AND IsAiAs RMS. 2009. Ontogênese da folha e das galhas induzidas por Aceria lantanae Cook (Acarina:Eriophyidae) em Lantana camara L. (Verbenaceae). Rev Bras Bot 32: 271-282.

NúÑEZ C AND SÁIZ F. 1994. Cecidios en vegetación autóctona de Chile de clima mediterráneo. An Mus Hist Nat Valpso 22: $57-80$

O'Brien TP AND MCCUlly ME. 1981. The Study of Plant Structure Principles and Selected Methods. Melbourne: Termarcarphi Pty, 345 p. 
OLIVEIRA DC, Christiano JCS, SOARES GLG AND ISAIAS RMS. 2006. Reações de defesas químicas e estruturais de Lonchocarpus mulherbergianus (Fabaceae) à ação do galhador Euphalerus ostreoides (Hemiptera: Psyllidae). Rev Bras Bot 29: 657-667.

OLIVEIRA DC AND ISAIAS RMS. 2009. Influence of leaflet age in anatomy and possible adaptive values of the midrib gall of Copaifera langsdorffii (Fabaceae: Caesalpinioideae). Rev Biol Trop 57: 293-302.

OLIVEIRA DC AND ISAIAS RMS. 2010. Redifferentiation of leaflet tissues during midrib gall development in Copaifera langsdorffii (Fabaceae). S Afr J Bot 76: 239-248.

Overbeck Ge, Muller SC, Fidelisa A, Fadenhauer JP, PILlaR VP, Blanco CC, BOLdRINI II, BOTH R AND FORNECEK ED. 2007. Brazil's neglected biome: The South Brazilian Campos. Perspect Plant Ecol Evol Syst 9: 101-116.

RAMAN A. 1987. On the cecidogenesis and nutritive tissues of the leaf galls of Garuga pinnata Roxburgh (Burseraceae) induced by Phacopteron lentiginosum Buckton (Pauropsyllinae: Psyllidae: Homoptera). Phytophaga 1: 141-159.

RAMAN A. 2011. Morphogenesis of insect-induced plant galls: facts and questions. Flora 206: 517-533.

ROBERTS IM, JONES AT AND AMRINE Jr JW. 1994. Ultrastructure of the black currant gall mite, Cecidophyopsis ribis (Acari; Eriophyidae), the vector of the agent of reversion disease. Ann Appl Biol 125: 447-455.

ROHFrITSCH O. 1992. Patterns in gall development. In: SHORTHOUSE JD AND ROHFRITSCH O (Eds), Biology of Insect-Induced Galls. New York: Oxford University Press, p. 60-86.

ROHFRITSCH O AND SHORTHOUSE JD. 1982. Insect galls. In: KAHL G AND SCHELL N (Eds), Molecular Biology of Plant Tumors. New York: Academic Press, p. 131-151.
SÁIZ F AND NúÑEZ C. 1997. Estudio ecológico de las cecidias del género Schinus, especialmente lãs de hoja y de rama de S. polygamus y Schinus latifolius (Anacardiaceae), em Chile Central. Acta Entomol Chil 21: 39-59.

SÁIz F AND NúÑEZ C. 2000. Cecidias de hoja y de rama de Schinus polygamus (Cav.) Cabr. (Anacardiaceae): doble agente formador o secuencia temporal de cecidias formadas por huespedes diferentes? Rev Chil Entomol 27: 57-63.

SCHÖNROGGE K, HARPER LJ AND LICHTENSTEIN CP. 2000 The protein content of tissues in cynipid galls (Hymenoptera: Cynipidae): Similarities between cynipid galls and seeds. Plant Cell Environ 23: 215-222.

SIMPSON MG. 2006. Plant Systematics. Oxford, Elsevier Academic Press, 590 p.

SOLEREDER H. 1908. Systematic Anatomy of the Dicotyledons. Oxford: Clarendon Press, $1182 \mathrm{p}$.

SOUZA SCPM, KRAus JE, ISAIAS RMS AND NEVES LJ. 2000. Anatomical and ultrastructural aspects of leaf galls in Ficus microcarpa L.F. (Moraceae) induced by Gynaikothrips ficorum Marchal (Thysanoptera). Acta Bot Bras 14: 57-69.

Stone GN AND SchÖNROGGE K. 2003. The adaptive significance of insect gall morphology. Trends Ecol Evol 18: 512-522.

TAYLOR GS. 1992. The structure of the eggs of some Australian Psylloidea (Hemiptera). J Aust Entomol Soc 31: 109-117.

ThiÉBAuT M. 2000. A foliar morphometric approach to the study of Salicaceae. Bot Rev 66: 423-439. 